\title{
The United Kingdom Ministry of Defence and the European Union's electrical and electronic equipment directives
}

\author{
Julieanna Powell-Turner, Peter D. Antill, Richard E. Fisher \\ Centre for Defence Acquisition, Vincent Centre, Cranfield University, Defence Academy of the United Kingdom, Shrivenham SN6 8LA, United Kingdom
}

A R T I C L E I N F O

Article history:

Received 3 December 2015

Received in revised form

26 July 2016

Accepted 26 July 2016

Keywords:

Defence

European

Union

Environment

Policy

UK

MOD

\begin{abstract}
A B S T R A C T
The growth of the generation of Electrical and Electronic Equipment (EEE), and the use of hazardous substances in the production of these items, has required legislation to minimise the harm to the environment that their existing use, ultimate disposal and continued growth of the sector may pose. The European Union (EU) started to tackle this problem with the passing of two Directives in 2002, which focused on restricting the use of hazardous substances (RoHS - 2002/95/EC) and organising the recycling or disposal of discarded electronic and electrical equipment (WEEE - 2002/96/EC). These Directives have been recently recast and their scope widened; however, one exception to them remains items specifically designed for defence and military purposes. This paper looks at how and why these European Directives were passed, the impact they have had on defence in the United Kingdom (UK) up to the present moment, what impact the further extension of those directives might have on UK defence policy and how the UK Ministry of Defence (MOD) has begun to prepare for any extension, including the use of alternative products from the commercial market, and substituting less harmful materials. The paper reviews the information available to carry out future decision making and what level of decision making it can support. Where the data is insufficient, it makes recommendations on actions to take for improvement.
\end{abstract}

(c) 2016 Elsevier Ltd. All rights reserved.

\section{Introduction}

The Information Technology revolution has spread right across society, with seventy-two percent of British adults using a PC every day (Office of National Statistics, 2015) and eighty-six percent of UK households having Internet access in 2015 (Office of National Statistics, 2015a). Extend this across the entire developed world and add in businesses and organisations in both the Public and Private Sectors, one can quickly see how much of a problem the generation of waste electrical and electronic equipment, known as e-waste, is becoming, as consumers, businesses and organisations upgrade their systems. Part of the problem is the toxic substances that are used in the production of these items, such as mercury, cadmium and lead. In an effort to tackle this problem, the European Union (EU) passed two Directives in 2002, which focused on restricting the use of hazardous substances (Restriction on Hazardous Substances (RoHS) - 2002/95/EC) and organising the recycling or disposal of discarded electronic and electrical equipment (Waste Electrical and Electronic Equipment (WEEE) - 2002/ 96/EC). However, there were a number of important exceptions,

\footnotetext{
* Corresponding author.

E-mail addresses: j.powell-turner@cranfield.ac.uk (J. Powell-Turner), p.antill@cranfield.ac.uk (P.D. Antill), r.fisher@cranfield.ac.uk (R.E. Fisher).
}

one being defence. This paper will look at what the e-waste problem actually consists of, the two European Directives designed to tackle it, how they have impacted on the UK Ministry of Defence (MOD) and UK defence and what impact any extension might have.

\section{The E-waste problem}

The last two decades have seen a revolution in Information Technology. This revolution has provided many benefits to society, with a whole host of commercial, medical, household, transport, scientific, educational, communications and defence applications, alongside the development of the Internet and World Wide Web (Atkinson and Castro, 2008). The development of this technology has been rapid, especially in terms of overall performance and storage capacity with developers such as Intel and Advanced Micro Devices Inc. (AMD) bringing out new products every eighteen months or so. Where the average consumer might have kept a PC for around four years in the mid-1990s, by the early $2000 \mathrm{~s}$, this had dropped to two years (Scanlon, 2004). It is not only PCs that now use this technology but household items such as televisions (for example the latest flat-screen Liquid Crystal Display (LCD) TVs), entertainment systems (such as MP3 players, tablets and game consoles), mobile phones, kitchen appliances and digital 
cameras, as does equipment in the wider economy, from medical scanners to supermarket checkouts. All of this has meant firstly, an increase in the number of products 'brought to market' by leading manufacturers in both the developed and developing worlds, for example, 302 million PCs were sold globally in 2014, compared to 134.7 million in 2000 (Statistic Brain, 2015). This has led secondly, to an increase in the e-waste generated across the globe, as people increasingly either buy to replace (rather than get something repaired) or buy to upgrade (keeping up with the latest developments). Indeed, as availability and affordability of this technology improves, e-waste generation is predicted to increase substantially in the developing world by 2020 (Schluep et al., 2009).

In addition, reports by the United Nations have continued to highlight the growing problem of e-waste:

- Manufacturing mobile phones and personal computers consumes three percent of the gold and silver mined worldwide each year; thirteen percent of the palladium and fifteen percent of cobalt (Schluep et al., 2009, p. 7);

- Modern electronics contain up to sixty different elements many valuable, some hazardous, and some both (Schluep et al., 2009, p. 6);

- Carbon dioxide emissions from mining and production of copper and precious and rare metals/rare earth elements used in electrical and electronic equipment are estimated at over twenty-three million tonnes (Schluep et al., 2009, p. 10);

- The global production of e-waste was estimated at 41.8 million tonnes in 2014 (Baldé et al., 2015, p. 8);

- This is expected to increase to around 50 million tonnes by 2018 (Baldé et al., 2015, p. 8);

- Countries like Senegal and Uganda can expect e-waste flows from PCs alone to increase by between four and eight fold by 2020 (Schluep et al., 2009, p. 49).

These problems are compounded by the fact that much of the e-waste is improperly handled, even in China, where imports have been banned. Agbogbloshie near Accra (Ghana), Guiyu (China), Taizhou (China), Delhi and Bangalore (India) all have e-waste processing areas. The uncontrolled burning, disassembly and disposal of such waste causes a number of environmental and health problems due to the release of a variety of toxic substances (Grossman, 2006).

\section{The EU'S WEEE directive}

The European Union's WEEE Directive (2002/96/EC), based on Article 175 of the European Community Treaty, was passed into European Law on 13 February 2003 (European Union, 2003a), but did not enter UK law until 1 July 2007. The overall aim of the legislation is to conserve landfill and to support more sustainable development by encouraging recycling. It requires producers to contribute towards the collection of their products at the end of their life-cycle and includes the costs of appropriate treatment of waste and specific targets for recycling and recovery (European Union, 2011). The Directive originally applied to the following categories of electrical and electronic equipment (BIO et al., 2008):

- Category 1 - Large Household Appliances;

- Category 2 - Small household Appliances;

- Category 3 - IT and Telecommunications Equipment;

- Category 4 - Consumer Equipment;

- Category 5 - Lighting Equipment

- Category 6 - Electrical and Electronic Tools;

- Category 7 - Toys, Leisure and Sports Equipment;

- Category 8 - Medical Devices;
- Category 9 - Monitor and Control Equipment;

- Category 10 - Automatic Dispensers.

After three-years, a review of Member States and stakeholders was conducted, which found that the proportion of e-waste being collected separately had jumped to around eighty-five percent but only thirty-three percent of that was being reported as having been treated according to legislation. In addition to this, approximately thirteen percent was still going to landfill and fifty-four percent was potentially going for sub-standard treatment either inside or outside the EU (European Union, 2008a). The directive has therefore been revised a number of times. Indeed, a look at the legislative history (Powell-Turner et al., 2011) shows that both the European Commission and Council have been willing to propose and pass amendments where there has been enough evidence to provide justification. Such a trend is likely to continue, especially as the directive was modified as recently as July 2012 with Directive 2012/19/EU, which came into force on 13 August 2012 and became effective on 14 February 2014 (European Union, 2012; European Commission, 2015). From 2016, EU members are required to recycle $45 \%$ of electronic equipment placed into the market, a figure that rises to $65 \%$ in 2019. All this however is linked to the producer responsibility regime, and it is unclear as to whether EU members will be able to count WEEE they consider to have been recycled outside of this regime, towards their targets using substantiated estimates. For example, a study by the charity WRAP indicates that between 400,000 and 550,000 $t$ of WEEE in the UK alone might be recycled in the light iron waste stream and thus remain unreported (Francavilla, 2015). From 15 August 2018, the legislation will apply to (European Union, 2012):

- All EEE, including photovoltaic panels, equipment containing ozone-depleting substances and fluorescent lamps containing mercury (certain types of EEE will continue to be excluded from the scope of this Directive);

- Increase the volume of EEE that Member States are required to collect and use;

- Require retail shops with an EEE sales area of at least $400 \mathrm{~m}^{2}$ to offer free take-back of very small WEEE;

- Introduce tighter requirements for shipping EEE to non-EU countries.

The ten categories that are in use currently will be replaced with six (European Union, 2012):

1. Temperature exchange equipment;

2. Screens, monitors, and equipment containing screens having a surface greater than $100 \mathrm{~cm}^{2}$;

3. Lamps;

4. Large equipment (any external dimension more than $50 \mathrm{~cm}$ ) including, but not limited to: Household appliances, IT and telecommunication equipment, consumer equipment, luminaires, equipment reproducing sound or images, musical equipment, electrical and electronic tools, toys, leisure and sports equipment, medical devices, monitoring and control instruments, automatic dispensers, equipment for the generation of electric currents;

5. Small equipment (no external dimension more than $50 \mathrm{~cm}$ ) including, but not limited to: Household appliances, consumer equipment, luminaires, equipment reproducing sound or images, musical equipment, electrical and electronic tools, toys/ leisure/sports equipment, medical devices, monitoring and control instruments, automatic dispensers, equipment for the generation of electric currents;

6. Small IT and telecommunication equipment (no external dimension more than $50 \mathrm{~cm}) .4$ 
It is important to note however, that the WEEE Directive does not apply to certain categories of electronic equipment, one important category being "equipment which is necessary for the protection of the essential interests of the security of Member States, including arms, munitions and war material intended for specifically military purposes" (European Union, 2012).

\section{The EU's RoHS directive}

The RoHS Directive (2002/95/EC), based on Article 95 of the European Community Treaty and passed into European Law at the same time, complemented the WEEE Directive in that it aimed to restrict the use of certain substances and reduce the generation of hazardous waste (European Union, 2003b). It became incumbent on businesses to show that their products did not contain more than a maximum level of certain substances, although the use of these substances in spares to repair equipment put on the market before 1 July 2006 was permitted. To illustrate compliance, producers had to provide evidence that their suppliers conformed. And in turn, they needed to present evidence from their suppliers and so on, down the supply chain. This Directive was first amended with Commission Decision 2005/618/EC (European Commission, 2005). This amendment recognised that in practical terms, it was virtually impossible to ensure the complete elimination of certain substances found in electrical and electronic products. It therefore set limits as to the amount of restricted substances that would be tolerated in new EEE when it entered the marketplace. Originally the RoHS Directive applied to eight out of the ten categories of EEE listed above, while two categories ( 8 - Medical Devices and 9 - Monitoring and Control Equipment) were exempt.

Despite the Directive often being termed the 'lead free' Directive, the term 'hazardous substances' actually applies to lead, mercury, cadmium, hexavalent chromium, polybrominated biphenyls or polybrominated diphenyl ethers, in quantities exceeding $0.1 \%$ by weight or $1000 \mathrm{ppm}$ in homogenous materials for lead, hexavalent chromium, mercury, polybrominated biphenyls, polybrominated diphenyl ethers and $0.01 \%$ by weight or $100 \mathrm{ppm}$ in homogenous materials for cadmium (European Commission, 2005).

The RoHS Directive is a legal instrument that ensures restrictions in the use of substances which affect product design and are implemented in a harmonised way throughout the EU. Since its introduction, it has prevented many thousands of tonnes of banned substances from being disposed of and potentially released into the environment (Bogaert et al., 2008). It has brought about important changes in the design of electrical and electronic products by increasing producers' awareness of product composition and toxicity. Other countries, such as the USA, China, Japan and Korea have followed the EU example and brought in similar legislation.

As with WEEE, this Directive has had a history of amendments (Powell-Turner, Antill and Hooper, 2011), and was recently recast by the EU (European Commission, 2011; European Union, 2011) as part of its overall commitment for a better regulatory environment. The directive came into force on 21 July 2011 and its provisions apply in stages through to 21 July 2021 . For example, from 21 July 2019, the restricted substances RoHS will cover will include butyl benzyl phthalate (BBP), dibutyl phthalate (DBP) and diisobutyl phthalate (DIBP) (MOD, 2015, p. 6). It covers improvements in implementation, enforcement and coherence as well as including two additional categories that were previously exempt medical devices and monitoring and control instruments (European Commission, 2011a). The EU held two extensive stakeholder consultations in the run-up to the recast, which revealed implementation-related problems. These included whether or not certain products fell within the scope of the Directive and the differences between Member States' methods for assessing product compliance and carrying out market surveillance. There has also been confusion over the relationship between RoHS and REACH (Registration, Evaluation, Authorisation and Restriction of Chemical substances) which has increased the risk of inadequate or inefficient implementation of the directive.

The key elements of the recast Directive are (European Commission, 2012):

- A gradual extension of the rules to all electrical and electronic equipment (EEE), cables and spare parts, with a view to full compliance by 2019;

- A review of the list of banned substances by July 2014, and periodically thereafter;

- Clearer and more transparent rules for granting exemptions from the substance ban;

- Improved coherence with the REACH Regulation on the Registration, Evaluation, Authorisation and Restriction of Chemicals;

- Clarification of important definitions; and

- CE marking denoting compliance with European norms reserved for electronic products that also respect RoHS requirements.

The WEEE and RoHS Directives are stimulating creativity in the next generation of green electronics. This creativity is designed into products, resulting in greener materials being utilised and new technologies created. In the Printed Circuit Board (PCB) industry, advocates are pushing to have more products designed with less bromine-based flame retardants (Westervelt, 2015). Various companies are looking ahead at the next round of banned substances which can be linked to the impact of the chemical restriction directive 'REACH' in the EU. This environmental trend towards banning substances requires organisations to be knowledgeable and ready for global environmental legislation (RoHS Guide, 2015).

Many component vendors have replaced traditional tin/lead solder alloys with pure or high-tin-content alloys. This presents designers with the long-term quality issue of tin whiskers, which are tiny tin filaments that grow over time with the potential of causing short circuits in electrical equipment, although there are other problems such as pad cratering, PCB delamination and solder joint cracking. If products have a long service life, are used in harsh environments with temperature and humidity extremes, or are used for critical operations such as in items of defence equipment, tin whiskers are a serious problem which cannot be ignored (Hall, 2006; Brown, 2015).

Developments in China on the protection of its rare earth elements (REE) may also encourage increased recycling as the supply of certain elements may become more unpredictable. An article in the online news service, EurActiv, claimed that the plan to tighten exports of key REE would be a real concern to manufacturers of "high-tech products ranging from computers to electric car batteries and wind turbines" (EurActiv.com, 2011) as well as the UK Defence Industry. Another article claimed that the tighter control of exports of dysprosium, terbium, thulium, lutetium and yttrium means that alternative supply chains will need to be created outside China. An increased focus on recovery and recycling should surely be able to meet some of this demand (Powell-Turner and Antill, 2015). The European Commission has also produced reports defining which raw materials are "critical" to EU industry (European Commission, 2010, 2014) as did the House of Commons Science and Technology Committee for the UK (House of Commons, 2011). For organisations working in the recycling and recovery field, these initiatives will be worth followi424 


\section{Defence - impact up to now}

As alluded to above, the restrictions imposed by both the RoHS and WEEE Directives do not apply to those specifically-designed items that are destined to be used in the defence and security sector. This stems from a number of different pieces of European Union legislation, the overarching one being Article 346 of the Treaty for the Functioning of the European Union (TFEU), formerly part of European Community law as Article 296 of the Treaty establishing the European Community (TEC) (European Union, 2008b).

It provides an exception to European Union law where such application would endanger the national security of a Member State. However, there have been problems with Article implementation. Article 296 is vague and open to interpretation in that firstly, the scope of the application article was not always clear, something that was not helped by the generic nature of the list of items mentioned (European Union, 2008a - see below). Secondly, uncertainties persisted on the conditions for the use of exemptions, since there is no commonly agreed definition of 'essential security interests' and what is necessary to protect them. Thirdly, the directive on public procurement, which was revised in 2004 and again in 2014 (see Crown Commercial Service (2015)), has been found by a number of Member States to be unsuited to defence procurement, as it fails to take into account the special nature of contracts in that area. As a result, EU Member States have used the exemption provided by Article 296 very differently and often in an extensive way. This is incompatible with the case law of the European Court of Justice, which states that Article 296 must be limited to exceptional and clearly defined cases (European Union, 2010). Moreover, the extensive use of the exemption hampers fair and open intra-European competition. Such exemptions go to the heart of the fundamental principles and operation of the internal market and were meant to be applied for only in cases when Member States can see no other way to protect their national security.

Basically, Article 296 (1)(a) allows Member States to keep secret information, the disclosure of which they consider contrary to the explicit interests of their national security. In addition, Article 296 (1)(b) allows Member States to undertake measures they consider necessary for the protection of their essential security interests and which are connected with the production of (and trade in) weapons, munitions and war material, however those are defined. Measures taken under Article 296 (1)(b) should not adversely affect the conditions of competition in the common market for products which are not intended for specifically military purposes, including 'dual use' items. The items to be included under the article were originally specified in a list, designated Council Decision 255/58 and dated 15 April 1958. It covered (European Council, 2008; European Union, 2008a):

- Portable and automatic firearms;

- Artillery and smoke, gas and flame throwing weapons;

- Ammunition for 1 and 2 above;

- Bombs, torpedoes, rockets and guided missiles;

- Military fire control equipment;

- Tanks and fighting vehicles designed specifically for military use;

- Toxic or radioactive agents;

- Powders, explosives and liquid or solid propellants;

- Warships and their specialist equipment;

- Aircraft and their equipment for military use;

- Military electronic equipment;

- Cameras designed specifically for military use;

- Other equipment (such as military parachutes, bridging equipment and searchlights);
- Specialised parts and items of material included in this list insofar as they are of a military nature;

- Machines, equipment and items exclusively designed for the study, manufacture, testing and control of arms, ammunition and equipment of an exclusively military nature included in this list.

The European Commission eventually issued an interpretive communiqué on 7 December 2006 - COM (2006) 779 Final - in an attempt to clarify what was covered under Article 296. It highlighted the fact that, given the nature of the products on the 1958 list and the explicit reference in Article 296 to "specifically military purposes", it was only the procurement of equipment which is designed, developed and produced for these purposes that could be exempted from European Union law. However, Article 296 can also cover the procurement of dual-use equipment for both military and non-military purposes, but only if the application of European Union law would oblige a Member State to disclose information damaging to its essential security interests. Crucially, it also highlights that military items included in the 1958 list are not automatically exempted from internal market rules. Any Member State seeking exemption under Article 296 must demonstrate that the exemption in question is necessary for the protection of its national security interests, this being the only condition which may justify such an exemption. General references to the country's geographical and political situation, history and alliance commitments are not deemed sufficient. The concept of 'essential security interests' gives Member States flexibility in the choice of measures to protect those interests but it is essential for national defence contracting authorities to assess each procurement contract with great care. As guardian of the Treaty, the Commission is entitled to verify - with due regard to the sensitive nature of the defence and security sector - whether the conditions for exempting procurement contracts on the basis of Article 296 have been fulfilled. If it finds that such conditions have not been fulfilled, then the Commission may place the matter directly before the Court of Justice, if it considers that a Member State is making improper use of the powers provided (European Commission, 2006).

Defence procurement accounts for a significant share of government spending in the European Union. Member States' combined defence budgets were worth just over $€ 186$ billion in 2013 , which included around $€ 37.5$ billion for investment and procurement (Platteau, 2015). Structurally, most of this expenditure is split into relatively small and closed national markets with Europe's defence sector remaining fragmented at the national level, with twenty-seven different customers and twenty-seven different regulatory frameworks. This fragmentation is a major obstacle to both intra-European cooperation and competition and creates extra costs, time delays and inefficiencies. It also has a negative impact on the competitiveness of Europe's Defence Industrial and Technological Base as well as on Member States' efforts to equip their armed forces in an adequate and timely manner. Given this situation, the European Commission felt that defence procurement law played an important part in sustaining this fragmentation. The majority of defence contracts were exempted from Internal Market rules and awarded on the basis of an individual state's procurement regulations, which means widely differing selection criteria, advertising procedures and so on. At the same time, individual defence ministry publication rates can vary considerably between Members. All of this taken together imposed a limit on market access for non-national suppliers and therefore hampered intraEuropean competition (European Union, 2009; European Commission, 2009).

The European Commission therefore passed Directive 2009/81/ EC on 13 July 2009 which aimed, at a European level, to introduce (European Union, 2009):1 
- Fair and transparent rules in order to help businesses access defence (and security) markets in other EU Member States;

- Flexibility for contracting authorities to negotiate (in detail) all the features of these complex contracts;

- The option for contracting authorities to insist on safeguards (from suppliers) to ensure that - (a) classified information is protected against unauthorised access; (b) there is security of supply so that armed forces receive deliveries in a timely manner, especially in the event of a crisis or conflict.

It covers:

- Military equipment - as covered by Council Decision 255/58 as well as related works and services;

- Sensitive security works and services - which involve access to classified information.

The procurement of non-sensitive and non-military equipment, works and services by national contracting authorities in the fields of defence and security are still covered under the general public procurement regulations in Directive 2004/18/EC as well as Directive 2014/24/EU. Both directives are obviously still subject to Article 346 of the current treaty. The broader security sector included, as the armed forces of Western states have in recent times, increasingly looked to work closer with their non-military security counterparts, enhancing standard operating procedures, interagency communications, as well as using equipment which is inter-operable and based on the same technology (Korski et al., 2009). Indeed, in an era of constrained budgets, it is likely to occur with a greater frequency meaning that better value for money can be attained with greater economies of scale from larger 'fleets' and their attendant support, servicing and maintenance contracts. Protection from the global threats of terrorism and organised crime requires the widespread use of sensitive equipment (especially in the realms of communications, data-gathering and surveillance) and access to classified information. This means that non-military security procurement can be just as sensitive as defence procurement and require the same security safeguards during the contracting process. The directive does not change the situation regarding trading with non-EU states, which are governed by World Trade Organisation (WTO) rules and in particular the Government Procurement Agreement (GPA) (European Union, 2010).

Given the current regulatory nature of defence e-waste, it is not possible to determine with any suitable accuracy, the impact of the removal of exclusions from either Directive. There is not currently a requirement for record keeping or notification when the exclusion is used; furthermore, it is not possible to identify how much defence e-waste exists overall (Hamlett, 2013). The List of Wastes (European Commission, 2000) does not specifically identify the defence industry. The Nomenclature of Economic Activities and the UK's Standard Industry Classification (SIC) scheme does allow for the identification of 'defence activities' (Code 84.2.2 and 84220 respectively); however, whilst is it a UK legal requirement to record the SIC code on a Waste Transfer Note (Waste (England and Wales) Regulations, 2011) or Hazardous Waste Consignment Note (Hazardous Waste (England and Wales) Regulations, 2005), the data interrogation tools provided by Eurostat (European Commission, 2016) and the Environment Agency (2015) do not provide a breakdown of that data to enable analysis by industry. Furthermore, if this data interrogation proved to be successful, it would only inform one element of the exclusion decision - the WEEE Directive.

\section{Restricted substances used in UK defence}

Until they were cancelled in 2014, two of the restricted substances that are used in UK defence were covered by Defence Standards (DefStan) 03-36 and 03-38 (Ministry of Defence, 2010a, 2010b). These are:

- Cadmium (Cd) - has been used to coat iron and steel to prevent corrosion since it was first manufactured on an industrial scale in the 1930s. The largest use today is in nickel-cadmium batteries (Wikipedia, 2015a). Its use in defence has remained extensive, and includes batteries for battlefield applications such as radio sets and protective coatings on items such as fasteners, springs, weapon systems, landing gear parts, armoured fighting vehicles and military bridges. The properties that make it useful include good protection against corrosion, galvanic compatibility to aluminium-based materials, a low coefficient of friction, reliable low electrical resistance and good electro-deposition characteristics.

- Hexavalent Chromium - Chromium (Cr) has been used extensively in the defence and aerospace sector for the production of thick hard-wearing coatings, as well as being added to steel to produce stainless steel. It was found on weapons belonging to statues in the burial pits of the Qin Dynasty near Xian, China dating from the late 3rd Century BC. Although buried over 2000 years ago, the bronze tips of crossbow bolts and swords found there showed little sign of corrosion as they had been coated with chromium (Wikipedia, 2015b). It has been mainly used to enhance wear resistance, for its anti-friction properties, to enhance corrosion resistance and for its conductivity. As such, it has been used on propeller hub components, inside gun barrels, on landing gear, hydraulic cylinders and rods, gas turbine engine components, pistons, rollers, pump components and valves.

- Another RoHS substance used extensively in UK defence is lead $(\mathrm{Pb})$. Lead has been used since the early Bronze Age, with lead beads found near Çatalhöyük in modern-day Turkey, dating from around 6400BC. It is a very common metal, easy to extract and work with, being highly malleable, ductile and easy to smelt. Lead has been used in a wide variety of applications, including its use in colour pigmentations (white, red and yellow), plumbing (especially in joining cast iron pipes), leaded fuels and pesticides. Many of these uses have now ceased, due to concerns over toxicity. However, as far as defence goes, lead is still used (in compound form) as a semiconductor in solar cells and infrared sensors (as an element), in the bullet core of small arms ammunition, as electrodes in lead-acid batteries, and as shielding from radiation. But perhaps its biggest use is when it is combined with tin to form solder and used in electrical components (Wikipedia, 2015c).

The use of materials covered by the RoHS Directive is not recorded where the industry is out of scope. Notwithstanding this, it is possible to identify total imports of the key materials identified in this paper (Fig. 1). This data demonstrates that the import tonnages of Lead, Cadmium and Chromium have mainly reduced since the 2006 implementation of the RoHS Directive, with the exception of Cadmium, albeit from a very low level use pre-RoHS. The post-RoHS import tonnages will be a total of excluded and exempt uses and there remains a significant tonnage of RoHS materials being used in UK industry overall.

\section{The search for alternatives}

Given the extensive use of cadmium, chromium and lead in UK defence and aware that both national and international legislation 426 


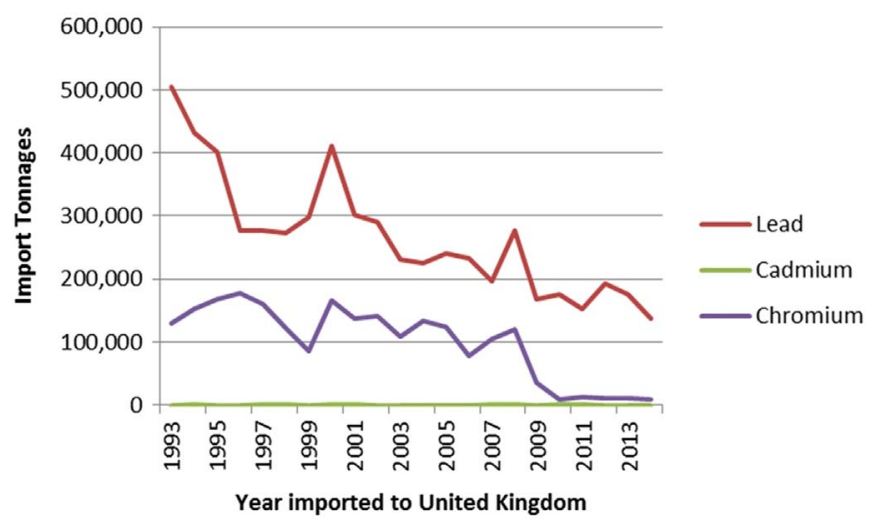

Fig. 1. Import quantities of lead, cadmium and chromium (BGS, 2016).427

has been moving to limit such use, the Ministry of Defence has begun looking at alternatives to both these substances, should WEEE and RoHS Directives be extended. Table 1 provides a summary of the substances that had been analysed up to the point at which the DefStan for cadmium was produced, while Tables 2 and 3 list commonly available alternatives for hard chromium electroplating of original equipment and for repairing already in-use equipment. Despite the DefStan being cancelled, whatever alternative is chosen, it has to contain a number of characteristics. The most important is corrosion resistance and is applicable to virtually all its intended uses. In addition and in the context of this paper, it must be environmentally benign and cost-effective. Other desirable characteristics include (Ministry of Defence, 2010, p. 24):

- Appearance - this can be important cosmetically or for camouflage purposes;

- Adherence to the underlying material;

- Influence on the properties of the underlying material. The most important of these is hydrogen embrittlement of certain materials such as high-strength steels;

- Torque/tension characteristics (relevant to fastener applications);

- Electrical conductivity (relevant to electrical connectors);

- Galvanic compatibility with the underlying material, e.g. compatibility with aluminium alloys;

- Process capable of coating a range of sizes of components including recesses and bores;

- Compatible with aerospace fluids (e.g. de-icing compounds, oils, grease);

- Easy disassembly (friction properties and low-volume corrosion products).

HVOF - High Velocity Oxy-Fuel process

ESD - Electro-Spark Deposition process

PEO - Plasma Electrolytic Oxidation

PVD - Physical Vapour Deposition

CVD - Chemical Vapour Deposition

WC - used as a generic term for Tungsten Carbide

WC-Co-Cr - Tungsten Carbide-Cobalt-Chromium

$\mathrm{CrC}$ - used as a generic term for Chromium Carbide

$\mathrm{Ni}$ - Nickel

$\mathrm{Si}-$ Silicon

C - Carbon

B - Boron

As with the alternatives to Cadmium, any substance used as an alternative to Chromium (to avoid the use of hexavalent chromium) has to meet certain performance parameters. These include (Ministry of Defence, 2010b, p. 32):
- Enhance corrosion resistance of the underlying material;

- Provide an element of quality control by generating colours relevant to some applications which are related to the thickness of the coating;

- Provide adhesion for subsequent painting;

- Electrically conductive - important as a design requirement. e.g. radio frequency screening;

- Having a simple, inexpensive process (although this depends upon the component size - see Fig. 2);

- Having a resilient process - low sensitivity to process variations and substrate chemistry (for example, effective on a range of aluminium alloys);

- Possess a degree of self-healing when damaged.

The major difficulty with looking to remove the use of lead in the manufacture of electrical and electronic components mainly centres on the reliability of non-lead solders. The increasing reliance of defence contractors on Commercial-Off-The-Shelf (COTS) solutions in critical military technologies is due to its impact on the time-to-market and on cost savings (Hall, 2006). Also many component vendors have replaced traditional tin/lead solder alloys with pure or high-tin-content alloys. This presents designers with the potential long-term quality issue of tin whiskers, which are tiny tin filaments that grow over time with the potential of causing electrical shorts in equipment. If products have a long service life, are used in harsh environments with temperature and humidity extremes, or are used for critical operations, tin whiskers are a serious problem which cannot be ignored (Wilson, 2009). In the context of resource use and scarcity and the impacts of diminishing supplies to the UK defence industry (Powell-Turner and Antill, 2015), it's worth noting that the drivers for alternatives are not solely due to the hazardous nature of the existing material. Cadmium, Chromium and Lead are all identified as 'Limited availability, future risk to supply' (House of Commons, 2011).

\section{Possible future impact on UK defence}

As indicated above, military equipment is one of the product categories that is currently exempted in the WEEE and RoHS Directives and in line with this, MOD Policy gives specific mandates on the use of permissive dis-applications or exemptions with a particular emphasis on the essential interest of Defence, national security or for specifically military equipment (MOD, 2015, p. 6). However, given the almost continuous legislative 'tinkering' that has gone on since they were introduced, and the push to include two previously excluded categories (medical devices/monitoring and control equipment) in the latest legislative recast, it is unclear just how long this 'protected' status will last. As indicated above, several of the materials covered by the directives are used extensively in the manufacture of defence equipment and consumables used by the UK Armed Forces. Any such removal of the exemption would have an impact on how the UK generates military capability, although much would depend on the nature of the legislation, what it covered and whether it was phased in over time. For example, lead is a vital component in small arms ammunition. If the MOD needed to comply with a recast directive without sufficient time to develop a suitable alternative, it would have consequences for the conduct of operations as well as small arms and marksmanship training.

Another example is the increased digitisation of the battlespace, and the increasing use of electronic systems in military hardware, not only in large capital assets such as aircraft, tanks and warships, but also equipment designed to be used by the individual soldier. A complicating factor in this increased use of electronics is the increasing use of COTS technology in military 
Table 1

Summary of cadmium-coating alternatives (Ministry of Defence, 2010a, pp. 5-6).

\begin{tabular}{|c|c|c|c|c|}
\hline Option & UK availability & $\begin{array}{l}\text { Initial cost (relative to cadmium } \\
\text { coating) }\end{array}$ & Capabilities & $\begin{array}{l}\text { Current status for cadmium replacement in military } \\
\text { applications }\end{array}$ \\
\hline Electro-deposited zinc & Many suppliers & Similar or slightly less & $\begin{array}{l}\text { Most obvious replacement from process stand- } \\
\text { point but properties limitation }\end{array}$ & Virtually no applications \\
\hline Hot-dip zinc ("galvanising") & Many suppliers & About same & $\begin{array}{l}\text { Thicker coats than cadmium } \\
\text { Durable in many outdoor atmospheric } \\
\text { environments }\end{array}$ & Virtually no applications \\
\hline Sherardise zinc & Few suppliers & About same & Thicker coats than cadmium & Virtually no applications \\
\hline Electro-deposited $\mathrm{Zn}-\mathrm{Ni}$ & Many suppliers & Slightly higher & $\begin{array}{l}\text { Most obvious replacement from process stand- } \\
\text { point } \\
\text { Some useful properties } \\
\text { Can coat internals }\end{array}$ & $\begin{array}{l}\text { Used in automobile industry and for some military and } \\
\text { aerospace applications }\end{array}$ \\
\hline Electro-deposited Zn-Co & Some suppliers & Slightly higher & $\begin{array}{l}\text { Reasonable replacement from process standpoint } \\
\text { Some useful properties } \\
\text { Can coat internals }\end{array}$ & Not much present utilisation but may increase \\
\hline Electro-deposited tin-zinc & Some suppliers & Slightly higher & $\begin{array}{l}\text { Some promising properties but also some appar- } \\
\text { ent technical limitations }\end{array}$ & Not much present utilisation but may increase \\
\hline $\begin{array}{l}\text { Ion Vapour Deposited } \\
\text { ("IVD") Aluminium }\end{array}$ & Commercial but limited suppliers & Significantly higher & $\begin{array}{l}\text { Most appropriate "drop-in" on technical grounds } \\
\text { but some limitations (internals) }\end{array}$ & $\begin{array}{l}\text { Much long-term use in USA (aerospace qualified) } \\
\text { especially for general components } \\
\text { Some use in UK }\end{array}$ \\
\hline Electro-deposited aluminium & $\begin{array}{l}\text { One supplier in USA and one in Ger- } \\
\text { many - No UK supplier (except for } \\
\text { electrical contacts) }\end{array}$ & $\begin{array}{l}\text { Significantly higher (Very high set-up } \\
\text { costs) }\end{array}$ & $\begin{array}{l}\text { Attributes similar to IVD-Al } \\
\text { Potential for fasteners and electrical connectors } \\
\text { Hazardous process }\end{array}$ & $\begin{array}{l}\text { Appears to be gaining ground in USA for some military } \\
\text { and aerospace applications }\end{array}$ \\
\hline $\begin{array}{l}\text { Aluminium-zinc or } \mathrm{Al}+\mathrm{Zn} \text { loa- } \\
\text { ded inorganics or organics }\end{array}$ & $\begin{array}{l}\text { Few suppliers of Al-ceramic type } \\
\text { More suppliers of other variants }\end{array}$ & $\begin{array}{l}\text { Al-ceramic type significantly higher } \\
\text { Some of others may be lower }\end{array}$ & $\begin{array}{l}\text { Process requires curing at elevated temperatures } \\
\text { Not suitable for electrical connectors }\end{array}$ & $\begin{array}{l}\text { Al-ceramic type have some applications in aircraft } \\
\text { engines and landing gear } \\
\text { Other types widely used as cadmium substitutes in } \\
\text { automobile industry }\end{array}$ \\
\hline Electro-less $\mathrm{Ni}$ & Many suppliers & Higher & Only acts as barrier coating & Little application in Military \\
\hline Electro-less Ni/PTFE composite & Yes & Higher & Candidates for electrical connectors & Accepted for use in US Mil Specs \\
\hline $\begin{array}{l}\text { Corrosion-resistant materials as } \\
\text { base metal }\end{array}$ & Many available & $\begin{array}{l}\text { Most options involve much higher in- } \\
\text { itial cost but with potential for lower } \\
\text { "life-cycle" costs }\end{array}$ & $\begin{array}{l}\text { Eliminates any coating for corrosion protection } \\
\text { except where in contact with galvanically in- } \\
\text { compatible material see C.9.6 } \\
\text { One high-strength corrosion-resistant steel (po- } \\
\text { tential for landing gear) is under final evaluation } \\
\text { in USA } \\
\text { Fibre-reinforced polymers possible for niche ap- } \\
\text { plications (e.g. some electrical connectors) }\end{array}$ & $\begin{array}{l}\text { Some grades of stainless steel and Ni-base superalloys } \\
\text { used in several military applications in severe (e.g. in } \\
\text { marine/aircraft) environments } \\
\text { Titanium alloys used in aircraft }\end{array}$ \\
\hline Thermal-sprayed aluminium & Many suppliers & Higher & $\begin{array}{l}\text { Thick, rough coatings } \\
\text { Not suitable for small diameter internals }\end{array}$ & $\begin{array}{l}\text { Suitable for large components and structures } \\
\text { Some use of landing gear }\end{array}$ \\
\hline Electro-plated Al-Mn & Not yet commercial & Higher & & Not yet evaluated for Military \\
\hline Sputtered aluminium & Not yet commercial & Higher & $\begin{array}{l}\text { Useful for internal surfaces } \\
\text { No hydrogen embrittlement }\end{array}$ & Very limited use by US Military \\
\hline $\begin{array}{l}\text { Chemical Vapour Deposition of } \\
\text { aluminium }\end{array}$ & At research stage & Higher & Useful for internal surfaces & Not yet evaluated for Military \\
\hline Electro-plating with ionic liquids & At research stage & Higher & Not yet used & None as yet ${ }_{N}$ \\
\hline
\end{tabular}


Table 2

Commonly available alternatives for hard chromium electroplating of original equipment (Ministry of Defence, 2010b, p. 6).

\begin{tabular}{|c|c|c|c|}
\hline $\begin{array}{l}\text { Thin Coating } \\
(\text { few } \mu \mathrm{m}) \\
\text { WEAR } \\
\text { not } \\
\text { corrosion }\end{array}$ & $\begin{array}{l}\text { Thick coating } \\
\text { (up to about } 0.3 \mathrm{~mm} \text { ) } \\
\text { WEAR + somecorrosionresistance }\end{array}$ & $\begin{array}{l}\text { Thick coating } \\
\text { (up to about } 0.3 \mathrm{~mm} \text { ) } \\
\text { WEAR + CORROSION RESISTANCE }\end{array}$ & $\begin{array}{l}\text { Thick coating } \\
\text { (up to about } 0.3 \mathrm{~mm} \text { ) } \\
\text { CORROSION } \\
\text { + some } \\
\text { wear } \\
\text { resistance }\end{array}$ \\
\hline $\begin{array}{l}\text { PVD:- } \\
\text { TIC, CrC, TiN, CrN } \\
\text { (Difficult to strip) } \\
\text { Limited to small components }\end{array}$ & $\begin{array}{l}\text { HVOF }^{\mathrm{a}} \\
\text { (WC-Co) } \\
\text { Plasma spray for some internal surfaces } \\
\text { (WC-Co Triballoy) }\end{array}$ & $\begin{array}{l}\text { HVOF }^{\mathrm{a}} \\
\text { (WC-Co-Cr, WC-CrC-Ni/Cr) } \\
\text { CVD tungsten } \\
\text { carbide tungsten }\end{array}$ & $\begin{array}{l}\text { HVOF }^{\mathrm{a}} \\
\text { (Ni-Cr-Si-C-B, } \\
\mathrm{CrC}-\mathrm{Ni} / \mathrm{Cr}^{\mathrm{b}} \text {, } \\
\mathrm{Ni}-\mathrm{Cr} \text { metallic) } \\
\text { Electroless } \\
\text { Nickel (also for internals) }\end{array}$ \\
\hline
\end{tabular}

NOTES

Comments on corrosion relate to saline water - see also Clause 6.4.

Thin coatings ( < about $50 \mu \mathrm{m}$ ) difficult to apply by thermal spray methods.

See Clause 6.6 for alternative thermochemical process.

" $\mathrm{CrC}-\mathrm{Ni} / \mathrm{Cr}$ coatings can be used at higher temperatures than WC-base coatings.

`Relatively new process (8.5.2.2): little track record, one "supplier", max thickness $100 \mu \mathrm{m}$.

a See Def Stan 03-43.

b $\mathrm{CrC}-\mathrm{Ni} / \mathrm{Cr}$ coatings can be used at higher temperatures than WC-base coatings.

${ }^{\mathrm{c}}$ Usually up to $0.1 \mathrm{~mm}$ : see 8.2 .2 .2 and 9.4 .6 for varieties of electroless nickel.

Table 3

Commercially available alternatives for hard chromium electroplating for rebuild/ repair (Ministry of Defence, 2010b, p. 7).

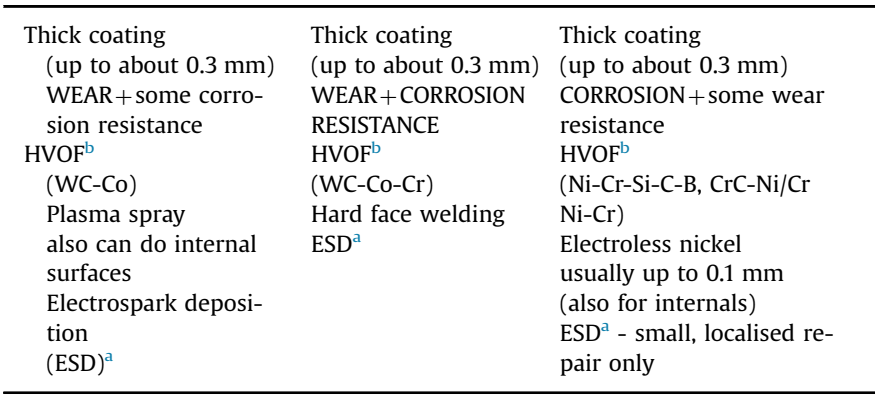

NOTES

Comments on corrosion relate to saline water - see also Clause 6.4.

For thicker, build-up coatings using HVOF - see Clause 6.3.3.

a See clause 6.7.

b Def Stan 03-43.

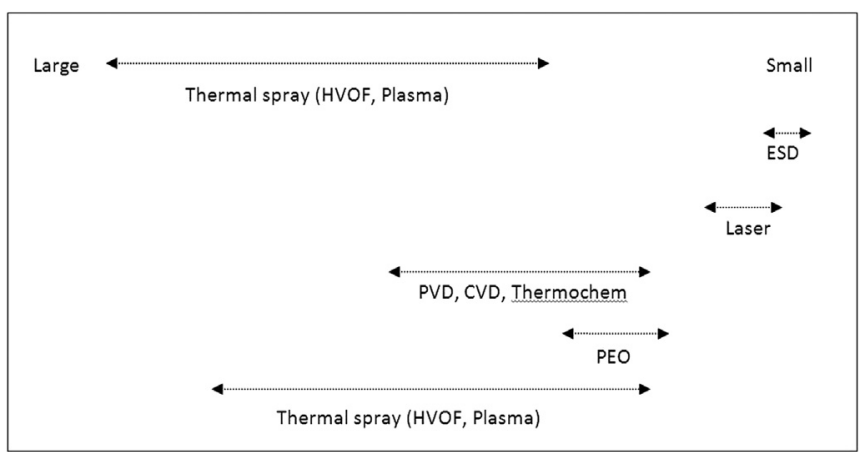

Fig. 2. Relationship between process and component size (Ministry of Defence 2010b, p. 7).y 49 (2016) 422-432

systems, forcing defence contractors to face the realities of the steady movement towards a "lead-free" global electronics environment (Howard, 2008; Curtiss-Wright, 2015). The effects of this have only recently started to be seen in the UK. Most component manufacturers have been unable to economically convert the whole of their back-catalogues to comply with the RoHS Directive. In many cases manufacturers have withdrawn certain components from the market, perhaps flagging those particular ones to be redesigned in the future. While some suppliers have made special provision for the needs of the defence and aerospace sector (Reynolds, 2008), there is usually only a certain amount of stock held along the supply chain, so once those stocks have been depleted, they are gone. In the commercial world, this occurs much more as a-matter-of-course, so companies are factoring in short-to-medium term component obsolescence virtually from the start. Almost as soon as the component is released into the marketplace, they are designing the replacement - an example being how quickly PC components become obsolescent and are replaced by the next generation. However, a great deal of military equipment is in service for a far longer time period than many of the products and systems found in the commercial world. For example, a company may well change a salesman's car after about three years when a new model appears, but the in-service life for a tank, warship or aircraft could be as much as forty years (Hall, 2006; Wilson, 2009). Having to support military equipment for that length of time currently forces defence companies to divert resources away from research and development (R\&D) to timeconsuming sustainment tasks which could include (Hall, 2006).

All this not only diverts a company's engineering resources away from their other tasks (including R\&D) but is often not in their core competences, forcing the company to outsource this process. This may require additional negotiations with the customer/end-user, complicating the approvals process. If the WEEE and RoHS Directives are extended to cover military equipment, this can only serve to complicate an already complex system. This is not so much a problem for the design and integration of future defence systems as COTS components have not only been complying with the RoHS Directive for several years but future components can be designed from the ground-up with the RoHS Directive in mind. Another potential impact (especially in an era of constrained defence budgets) will be with regard to the longer 42 \$erm support of already in-service equipment, especially as stocks of older components are used up and replacements sought. In addition, the MOD and defence industry will have to play their part in following the WEEE Directive. They must ensure that any e-waste generated is collected and processed accordingly. This may mean additional resources will have to be diverted from other areas of defence, problematic in the era of austerity (Hall, 2006), a factor that could be complicated should the directives be extended to additional substances, such as beryllium, arsenic, selenium and tin (Groß et al., 2008).

Many companies that operate within the UK Defence Industrial 
Sector have links to the commercial market, and some have already taken steps to anticipate an extension of the WEEE and RoHS Directives to cover defence. For example, BAE Systems, Rolls Royce and Airbus all participate in the Pb-Free Electronics Risk Management (PERM) Council (formerly the LEAP (Lead-free Electronics in Aerospace Project) Consortium) whose role is to provide leadership and coordinate industry activity relating to the use of lead-free electronics in aerospace and defence. It has also prepared a number of specifications relating to environmental standards (IPC Association, 2015). Furthermore, EADS, Bombardier Aerospace, Rolls Royce and Boeing (among others) decided to team up to address this potentially difficult transition, by creating the International Aerospace Environmental Group (IAEG) to jointly define the technical solutions, the validation tests protocols, and the configuration management rules that will be enforced throughout the Aerospace Industry and its supply chain in the coming years (Boeing, 2012).

While it is possible that defence itself may become fully subject to the provisions of the EEE Directives, there are three additional scenarios by which tighter legislation could be imposed in any future follow-on to the RoHS Directive recast:

- Firstly, improved scientific knowledge about the harmful effects of materials not presently prohibited will put pressure on legislators to extend the list of substances so as to eliminate any pollution/risk caused. Such substances could include selenium, antimony, zinc, silver, tin and chemicals such as Hexabromocyclododecane (HBCDD), Diethylhexyl Phthalate (DEHP), BBP, DBP and DIBP (Trencome, 2011; Groß et al., 2008; Brigden et al., 2005).

- Secondly, an ever increasing quantity of waste material may be generated, and this may not be matched by the commensurate increases in waste management related infrastructure. However, as there is a move from the traditional linear economy of take, make, dispose to a circular economy where products, components and materials are kept at their highest utility and value at all times through a regenerative process it is likely that we'll see further investment into the wastes management infrastructure to ensure materials are recovered and recycled (Ellen MacArthur Foundation, 2014).

- Thirdly, reserves of strategic minerals, particularly metals and rare earths elements, are diminishing rapidly due to accessibility, use and political instability. It is likely that the reduced availability of strategically important materials will not only push the recovery and recycling of materials but legislation may need to be enacted to control their distribution and use (European Commission, 2010; Graedel, 2010). We have already seen the intervention from the World Trade Organisation (WTO) in 2014 over export disputes which generated unease in the West as to China's future intentions. In March 2014, a decision was made by the WTO against China which lost its dispute over exports to Japan, the United States and the European Union. The case, taken over export restrictions, stated that it gave the Chinese an unfair competitive disadvantage in key high tech sectors (WTO, 2015). However export volumes continue to decrease and supplies have been diverted to the domestic Chinese market, leading to a downward pressure on the prices of those products. Therefore the gap between domestic prices and world prices continues to provide Chinese downstream processors with a competitive advantage. This situation will probably continue as China consolidates production and creates more value-added applied materials by keeping a crucial link of the supply chain in-country. All this is likely to have an impact on the future scope and enforcement of the WEE and RoHS directives, as modern electronics contain these strategically important 43materials, especially in the modern defence environment with its growing reliance on the digital battlespace.

\section{Conclusion}

This paper has shown that, given the legislative history of both the WEEE and RoHS Directives, and that the recent recast of the ROHS Directive has included two previously excluded categories of WEEE, it will be important for the MOD to keep abreast of what is happening. Any changes could have a sizeable impact on the formulation and conduct of UK defence policy, especially in an era of constrained budgets.

Prior to any consideration of extending the scope of the Directives by removing the defence exclusions, data quality must be improved as there's insufficient evidence on which to base an informed decision on the impact of defence e-waste. The UK MOD should work with its Government colleagues - principally the Environment Agency - to determine the extent of their waste disposal activities. Furthermore, improvements to the management of e-waste may be made by requiring the relevant materials to be individual monitored and volumes accounted for. This would provide evidence of reducing the environmental burden by the increased use of COTS solutions and the use of alternative materials. This resource management approach could well be expanded to include other Strategically Important Metals (SIM) and Rare Earth Elements (REE) to help inform wider resource scarcity policy.

\section{References}

Atkinson, R., Castro, D., 2008. Digital Quality of Life: Understanding the Personal and Social Benefits of the Information Technology Revolution, dated 4 October 2008. Located at 〈http://ssrn.com/abstract $=1278185\rangle$, as of 2 November 2015.

Baldé, C., Wang, F., Kuehr, R., Huisman, J., 2015. The Global E-Waste Monitor - 2014 United Nations University, IAS - SCYCLE (Bonn). Located 〈http://i.unu.edu/ media/unu.edu/news/52624/UNU-1stGlobal-E-Waste-Monitor-2014-small.pdf〉, as of 1 October 2015.

BIO, IEEP and VITO, 2008. Study to Support the Impact Assessment of the RoHS Review - Final Report, dated 16 September 2008. Located at $\langle$ http://ec.europa. eu/environment/waste/weee/pdf/ia_report.pdf), as of 3 November 2015.

Boeing, 2012. Boeing 2012 Environmental Report. Located at $\langle$ http://www.boeing. com/resources/boeingdotcom/principles/environment/pdf/2012_environm ent_report.pdf, as of 3 November 2015.

Bogaert, S., van Acoleyen, M., van Tomme, I., De Smet, L., Fleet, D., Salado, R., 2008 Study on RoHS and WEEE Directives - Final Report, Report No. 30-CE-0095296/ 00-09, Reference 06/11925/AL, Arcadis Ecolas/RPA, March 2008. Located at 〈http://ec.europa.eu/environment/waste/weee/pdf/rpa_study.pdf〉, as of 2 October 2015 .

Brigden, K., Labunska, I., Santillo, D., Allsopp, M., 2005. Recycling of Electronic Wastes in China \& India: Workplace \& Environmental Contamination, Greenpeace International, August 2005. Located at $\langle$ http://www.greenpeace.org/in ternational/PageFiles/25134/recycling-of-electronic-waste.pdf $\rangle$, as of 29 October 2015.

British Geological Survey, 2016. World mineral statistics data webpage, June 2016 Located at 〈http://www.bgs.ac.uk/mineralsuk/statistics/wms.cfc?meth od=searchWMS $\rangle$, as of 13 June 2016.

Brown, L., 2015. 'Lead Free Technology in Mil/Aero Electronics' webpage, Military Embedded Systems website, updated 22 October 2015. Located at $\langle$ http://milembedded.com/articles/lead-free-technology-milaero-electronics/ $\rangle$, as of 3 November 2015

Crown Commercial Service, 2015. A Brief Guide to the EU Public Contracts Directive (2014), February 2015. Located at /https://www.gov.uk/government/uploads/ system/uploads/attachment_data/file/472985/A_Brief_Guide_to_the_EU_Pub lic_Contract_Directive_2014_-_Oct_2015_1_.pdf), as of 16 October 2015.

Curtiss-Wright Defense Solutions, 2015. "Tin Whisker' Research for Lead-Free Components in Defense Applications Announced by Curtiss-Wright" webpage, 19 January 2015. Located at $\langle$ http://buyersguide.mae.pennnet.com/curtiss wright-defense-solutions/pressrelease/tin-whisker-research-for-leadfree-com ponents-in-defense-applications-announced-by-curtisswright.html $\rangle$, as of 4 November 2015.

Ellen MacArthur Foundation, 2014. Towards the Circular Economy Vol. 3: Accelerating the Scale-up Across Global Supply Chains, 24 January 2014. Located at 〈http://www.ellenmacarthurfoundation.org/publications/towards-the-circulareconomy-vol-3-accelerating-the-scale-up-across-global-supply-chains $\rangle$, as of 3 December 2015.y 49 (2016) 422-432 
Environment Agency, 2015. Hazardous Waste Data Interrogator (2014). Available at: 〈https://data.gov.uk/dataset/hazardous-waste-interrogator-2014〉, (accessed 13.06.16)

EurActiv.com, 2011. 'EU, US, Japan should cooperate on rare earth supply', updated 27 February 2011. Located at $\langle$ http://www.euractiv.com/sustainability/eu-us-ja pan-cooperate-rare-earths-supply-news-501917〉, as of 26 October 2015.

European Commission, 2000. Commission Decision of 3 May 2000 replacing Decision 94/3/EC establishing a list of wastes pursuant to Article 1(a) of Council Directive 75/442/EEC on waste and Council Devision 94/904/EC establishing a list of hazardous waste pursuant to Article 1(4) of Council Directive 91/689/EEC on hazardous waste. Located at 〈http://eur-lex.europa.eu/LexUriServ/LexUr iServ.do? uri=CONSLEG:2000D0532:20020101:EN:PDF>, as of 13 June 2016.

European Commission, 2005. Commission Decision of 18 August 2005 amending Directive 2002/95/EC of the European Parliament and of the Council for the purpose of establishing the maximum concentration values for certain hazardous substances in electrical and electronic equipment (notified under document number C(2005) 3143). Located at $\langle$ http://eur-lex.europa.eu/LexUr iServ/LexUriServ.do?uri=CELEX:32005D0618:EN:HTML>, as of 27 October 2015.

European Commission, 2006. Interpretive Communication on the Application of Article 296 of the Treaty in the field of defence procurement', COM (2006) 779 FINAL, dated 7 December 2006. Located at $\langle$ http://eur-lex.europa.eu/LexUr iServ/LexUriServ.do? uri=COM:2006:0779:FIN:en:PDF>, as of 25 October 2015

European Commission, 2009. Defence Procurement - Frequently Asked Questions' Brussels, 28 August 2009. At $\langle$ http://ec.europa.eu/internal_market/pub licprocurement/docs/defence/faqs_28-08-09 en.pdf), as of 28 October 2015.

European Commission, 2010. Critical Raw Materials for the EU - Report of the Ad Hoc Working Group on Defining Critical Raw Materials, dated 30 July 2010. Located at 〈http://ec.europa.eu/DocsRoom/documents/5662/attachments/1/ translations/en/renditions/native〉, as of 3 November 2015.

European Commission, 2011. Recast of the RoHS Directive. Webpage located at 〈http://ec.europa.eu/environment/waste/rohs_eee/index_en.htm〉, as of 2 October 2013

European Commission, 2011a. Environment: Fewer risks from hazardous substances in electrical and electronic equipment, Press Release, dated 20 July 2011. Located at $\langle$ http://europa.eu/rapid/press-release_IP-11-912_en.htm〉, as of 28 October 2015.

European Commission, 2012. RoHS 2 FAQ. Webpage Located at $\langle$ http://ec.europa.eu environment/waste/rohs_eee/pdf/faq.pdf), as of 29 October 2015.

European Commission, 2014. Critical Raw Materials for the EU: Report of the Ad Hoc Working Group on Defining Critical Raw Materials, May 2014. Located at 〈http://ec.europa.eu/DocsRoom/documents/10010/attachments/1/translations/ en/renditions/native $\rangle$, as of 3 November 2015.

European Commission, 2015. Waste Electronic and Electrical Equipment. Webpage located at $\langle$ http://ec.europa.eu/environment/waste/weee/index_en.htm〉, as of 27 October 2015.

European Commission, 2016. Eurostat: Your key to European statistics Webpage. Available at: 〈http://ec.europa.eu/eurostat〉, (accessed: 13.06.16).

European Council, 2008. Extract of the Council Decision 255/58 of 15 April 1958 Located at $\langle$ http://register.consilium.europa.eu/pdf/en/08/st14/st14538-re04. en08.pdf, as of 4 November 2015.

European Union, 2003a. 'Directive 2002/96/EC of the European Parliament and of the Council of 27 January 2003 on waste electrical and electronic equipment (WEEE)' in the Official Journal of the European Union, Volume 46, Issue: 13 February 2003, pp. 24 - 38. Available at $\langle$ http://eur-lex.europa.eu/legal-content en/TXT/?uri=CELEX:32002L0096), as of 28 October 2015.

European Union, 2003b. 'Directive 2002/95/EC of the European Parliament and of the Council of 27 January 2003 on the restriction of the use of certain hazardous substances in electrical and electronic equipment' in the Official Journal of the European Union, Volume 46, Issue: 13 February 2003, pp. 19-23. Available at $\langle$ http://eur-lex.europa.eu/LexUriServ/LexUriServ.do?uri=0] L:2003:037:0019:0023:EN:PDF>, as of 29 October 2015

European Union, 2008a. 'Questions and answers on the revised directive on waste electrical and electronic equipment (WEEE)', Press Release MEMO/08/764, dated 03 December 2008. Available at $\langle$ http://europa.eu/rapid/pressReleasesAc tion.do? reference $=$ MEMO/08/764), as of 24 October 2015

European Union, 2008b. 'Consolidated version of the Treaty on the Functioning of the European Union - PART SEVEN: GENERAL AND FINAL PROVISIONS - Article 346 (formerly Article 296 TEC)', Official Journal of the European Union, Volume 51, Issue: 9 May 2008, p. 194. Located at $\langle$ http://eur-lex.europa.eu/legal-con tent/EN/TXT/PDF/?uri=CELEX:12012E/TXT\&from=en>, as of 4 November 2015

European Union, 2009. 'Directive 2009/81/EC of the European Parliament and of the Council of 13 July 2009 on the coordination of procedures for the award of certain works contracts, supply contracts and service contracts by contracting authorities or entities in the fields of defence and security, and amending Directives 2004/17/EC and 2004/18/EC', Official Journal of the European Union, Volume 52, Issue: 20 August 2009, pp. 76-137. At $\langle$ http://eur-lex.europa.eu/ LexUriServ/LexUriServ.do?uri=OJ:L:2009:216:0076:0136:EN:PDF>, as of 27 October 2015.

European Union, 2010. 'EU Law and Defence Procurement', Explanatory Memo, December 2010. Located at $\langle$ http://ec.europa.eu/internal_market/pub icprocurement/docs/defence/more on_defence_procurement_en.pdf $\rangle$, as of 24 October 2015.

European Union, 2011. 'Directive 2011/65/EU of the European Parliament and of the Council of 8 June 2011 on the restriction of the use of certain hazardous substances in electrical and electronic equipment (recast)', Official Journal of the
European Union, Volume 54, Issue: 1 July 2011, pp. 88-110. Located at $\langle$ http:// eur-lex.europa.eu/LexUriServ/LexUriServ.do?uri=OJ:L:2011:174:0088:0110:EN: PDF), as of 29 October 2015.

European Union, 2012. 'Directive 2012/19/EU of the European Parliament and of the Council of 4 July 2012 on waste electrical and electronic equipment (WEEE) (recast)', Official Journal of the European Union, Volume 55, Issue: 24 July 2012 pp. 38-71. Located at $\langle$ http://eur-lex.europa.eu/legal-content/EN/TXT/PDF/?ur $\mathrm{i}=$ CELEX:32012L0019\&from $=\mathrm{EN}\rangle$, as of 27 October 2015.

Francavilla, C., 2015. 'Producer Responsibility: Reforming Producer Rules' in ENDS Report 486 (August 2015), 28 July 2015, pp. 27-30. Located at $\langle$ http://www. endsreport.com/article/49113/producer-responsibility-reforming-producerrules $\rangle$, as of 27 October 2015.

Graedel, T., 2010. Metal Stocks in Society - Scientific Synthesis. Located at 〈http:// www.unep.org/resourcepanel/Portals/24102/PDFs/Metalstocksinsociety.pdf), as of 28 October 2015, United Nations Environment Programme.

Groß, R., Bunke, D., Gensch, C., Zangl, S., Manhart, A., 2008. Study on Hazardous Substances in Electrical and Electronic Equipment, Not Regulated by the RoHS Directive, dated 17 October 2008, Freiberg: Oko-Institut e.V. Located at $\langle$ http:// hse-rohs.oeko.info/fileadmin/user_upload/Documents/RoHS_Hazardous_Sub stances_Final_Report.pdf $\rangle$, as of 28 October 2015.

Grossman, E., 2006. 'Where Computers Go to Die - and Kill' at Salon, dated 10 April 2006. Located at 〈http://www.salon.com/news/feature/2006/04/10/ewaste〉, as of 29 October 2015

Hall, K., 2006. 'Lead-Free Revolution Hits Defence R\&D' in Electronics Weekly, 26 November 2006. Located at 〈http://www.electronicsweekly.com/news/design/ legislation/lead-free-revolution-hits-defence-rd-2006-11/>, as of 26 Octobe 2015.

Hamlett, W., 2013. Waste Management in the Army Acquisition Environment, Cranfield University, MSc Thesis, September 2013.

Hazardous Waste (England and Wales) Regulations, 2005. (SI2005/894) available at: 〈http://www.legislation.gov.uk/uksi/2005/894/made〉, (accessed 13.06.16).

House of Commons, 2011. Strategically Important Metals, Science and Technology Committee, HC726, 17 May 2011. Located at $\langle$ http://www.publications.parlia ment.uk/pa/cm201012/cmselect/cmsctech/726/726.pdf), as of 27 October 2015

Howard, C., 2008. 'Lead-free issues continue to plague mil - aero market, says DEMA engineer' in Military \& Aerospace Electronics, Volume 19, Issue 4 (April 2008). Available at $\langle$ http://www.militaryaerospace.com/index/display/articledisplay/325956/articles/military-aerospace-electronics/volume-19/issue-4/de partments/mae-forum-news/lead-free-issues-continue-to-plague-mil-aeromarket-says-dmea-engineer.html $>$, as of 4 November 2015

IPC Association, 2015. 'Pb-free Electronics Risk Management (PERM) Council' webpage, located at $\langle$ https://www.ipc.org/ContentPage.aspx?pageid=PERMCouncil>, as of 3 November 2015.

Korski, D., Serwer D., Chabalowski, M., 2009. A New Agenda for US-EU Security Cooperation, FRIDE, Working Paper 92, November 2009. Located at $\langle$ http:// fride.org/download/WP92_US_EU_Security_ENG_Jan10.pdf), as of 25 October 2015.

Ministry of Defence, 2010a. Guidance to the Use of Cadmium Alternatives in the Protective Coating of Defence Equipment, Defence Standard 03-36, Issue 2 (Publication Date: 25 June 2010).

Ministry of Defence, 2010b. Guidance to the Use of Alternatives to Hexavalent Chromium for the Protective Coating of Defence Equipment, Defence Standard 03-38, Issue 2 (Publication Date: 23 July 2010).

Ministry of Defence, 2015. Hazardous Material Management - Leaflet 5, Joint Service Publication 418 (Draft), seen 4 November 2015. JSP418 is being updated the current edition can be seen at $\langle$ https://www.gov.uk/government/publica tions/jsp-418-mod-corporate-environmental-protection-manual〉, as of 4 November 2015.

Office of National Statistics, 2015. 'Computer and Internet Use' in Statistical Bulletin: Internet Access - Households and Individuals 2015, 6 August 2015. Located at 〈http://www.ons.gov.uk/ons/rel/rdit2/internet-access-households-and-in dividuals/2015/stb-ia-2015.html\#tab-Computer-and-internet-use $\rangle$, as of 30 September 2015

Office of National Statistics, 2015a. 'Household Internet Access' in Statistical Bulletin: Internet Access - Households and Individuals 2015, 6 August 2015. At 〈http://www.ons.gov.uk/ons/rel/rdit2/internet-access-households-and-in dividuals/2015/stb-ia-2015.html $\rangle$, as of 30 September 2015

Platteau, E., 2015. Defence Data 2013, European Defence Agency, 31 March 2015 Located at 〈http://www.eda.europa.eu/docs/default-source/eda-publications/ eda-defence-data-2013), web as of 20 October 2015.

Powell-Turner, J., Antill, P., 2015. Will future resource demand cause significant and unpredictable dislocations for the UK Ministry of Defence? Resour. Policy 45, 217-226.

Powell-Turner, J., Antill, P., Hooper, G., 2011. Legal Trends - Initial Proof of Concept: Restriction of Hazardous Substances (RoHS), Contract Report No. DMS/JPT/PA/ GH1001/11, Contract Reference DSTL/SEA//4495, dated 19 May 2011.

Reynolds, C., 2008. 'Tin Lead components alive and well in military sector' in Military \& Aerospace Electronics, Volume 19, Issue 1 (January 2008). Available at $\langle$ http://www.militaryaerospace.com/articles/print/volume-19/issue-1/depart ments/opinion/tin-lead-components-alive-and-well-in-the-military-sector. html>, as of 26 October 2015.

RoHS Guide, 2015. 'Other RoHS Green Initiatives Worldwide' Webpage, Located at 〈http://www.rohsguide.com/rohs-future.htm〉, as of 15 October 2015.

Scanlon, K., 2004. Toxic TVs and Poison PCs, Silicon Valley Toxic Coalition (SVTC), located at $\langle$ http://svtc.org/wp-content/uploads/ppc-ttv1.pdf , as of 26 October 2015.y 49 (2016) 422-432 
Schluep, M., Hagelueken, C., Kuehr, R., Magalini, F., Maurer, C., Meskers, C., Mueller, E., Wang, F., 2009. Recycling - From E-Waste to Resources, United Nations Environment Programme (UNEP). Located at $\langle$ http://www.unep.org/pdf/Re cycling_From_e-waste_to_resources.pdf $\rangle$, as of 27 October 2015.

Statistic Brain, 2015. 'Computer Sales Statistics' webpage, dated 16 August 2015. Located at $\langle$ http://www.statisticbrain.com/computer-sales-statistics/〉, as of 19 October 2015.

Trencome, 2011. 'Selenium' and 'Antimony' at $\langle$ http://www.trencome.com/min ormetalsproducts.htm〉, and 'Zinc' at 〈http://www.trencome.com/base metalsproducts.htm>, as of 20 October 2013.

Westervelt, A., 2015. 'Flame Retardants May be Coming Off of Furniture, But They're Still in Your TV Sets' in The Guardian, dated 19 May 2015. Located at 〈http:/ www.theguardian.com/sustainable-business/2015/may/19/flame-retardantchemicals-tvs-electronics-hazard>, as of 15 October 2015.

Waste (England and Wales) Regulations, 2011 (SI2011/988). Available at: 〈http:// www.legislation.gov.uk/uksi/2011/988/made), (accessed 13.06.16).
Wikipedia, 2015a. 'Cadmium' webpage, At 〈http://en.wikipedia.org/wiki/Cadmium〉, as of 20 October 2015 .

Wikipedia, 2015b. 'Chromium' webpage, At $\langle$ http://en.wikipedia.org/wiki/Chro mium>, as of 20 October 2015.

Wikipedia, 2015c. 'Lead' webpage, at 〈http://en.wikipedia.org/wiki/Lead〉, as of 20 October 2015.

Wilson, J., 2009. 'Lead free RoHS on military electronics procurement', Military \& Aerospace Electronics, dated 1 April 2009. Located at $\langle$ http://www.militar yaerospace.com/index/display/article-display/358507/articles/military-aero space-electronics/volume-20/issue-4/features/special-report/lead-free-rohson-military-electronics-procurement.html $\rangle$, as of 24 October 2015.

World Trade Organisation (WTO), 2015. 'China - Measures Related to the Exportation of Rare Earths, Tungsten and Molybdenum', Dispute DS431, updated 22 June 2015. Located at $\langle$ https://www.wto.org/english/tratop_e/dispu_e/cases e/ds431_e.htm>, as of 3 December 2015432 